\title{
Influence of Arm Muscle Strength, Draw Length and Archery Technique on Archery Achievement
}

\author{
Hidayat Humaid ${ }^{1}$ \\ ${ }^{1}$ Faculty of Sports Science, Universitas Negeri Jakarta, Indonesia \\ Correspondence: Hidayat Humaid, Faculty of Sports Science, Universitas Negeri Jakarta, Kampus B, Jl. Pemuda \\ 10, Rawamangun, Jakarta 13220, Indonesia. E-mail: hhumaid@unj.ac.id
}

Received: January 16, 2014

Accepted: February 20, 2014 Online Published: February 28, 2014

doi:10.5539/ass.v10n5p28

URL: http://dx.doi.org/10.5539/ass.v10n5p28

\begin{abstract}
Archery is a sport that fires an arrow onto target face as precisely as possible. In order to have high accuracy, there is a need of a true and consistent archery technique. Arms muscle strength is the capital to perform an archery technique. Anyone may perform a correct archery technique when he/she has sufficient arms muscle strength to draw and hold the bow. In order to perform a correct archery technique, an athlete must be able to feel and control his/her technique well. This study examines four variables, consisting of three exogenous variables and one endogenous variable. The exogenous variables consist of arms muscle strength $\left(\mathrm{X}_{1}\right)$, pull length $\left(\mathrm{X}_{2}\right)$ and archery technique $\left(\mathrm{X}_{3}\right)$ and the endogenous variable consists of archery achievement of the FITA recurve round $\left(\mathrm{X}_{4}\right)$. The sample of this study is 62 male archery athletes of the FITA recurve round. The instrument of study is made through several methods, such as (1) composing variable indicators of study, (2) composing instrument lattice, (3) performing instrument test, (4) performing test on the validity and reliability of instrument. Results shows that arm muscle strength influence archery achievement.
\end{abstract}

Keywords: strength, arm muscles, archery, recurve

\section{Introduction}

Indonesia has created history in sports by winning the first silver medal for Indonesia in 1988 in the Olympic Games, Seoul, South Korea; in 1994 in Asian Games Hiroshima (Japan); and, in the World Championship in Jakarta. Afterwards, Indonesian athletes have never been able to compete at world level. Recently, Indonesian athletes' archery achievement is only at SEA GAMES level. Archery is a sport that fires an arrow onto target face as precisely as possible. In order to have high accuracy, there is a need of a true and consistent archery technique. The same statement is made by Mc Kinney (1977), that there is only simple movement in archery, no difficult movement, and an archer will achieve score for 1440 when he/she is able to repeat the same and true movement for 144 times. Archery is about firing an arrow onto a target at certain distance. There are some matters to consider: (1) Physical conditions, covering: arms muscle strength, body muscle strength, legs muscle strength, muscle durability, aerobic capacity, flexibility, body posture (pull length), coordination between eyes and arms. (2) Techniques, covering: basic archery technique, instruments tuning and suitability to body condition and posture, compensate, instrument quality. (3) Tactic, covering: control of archery order. (4) Psychology, covering: motivation, confidence, sportivity, anxiety, self-control, tenacity to overcome any pressure, concentration, etc. This study focuses on muscle strength, pull length, archery technique, and archery achievement factors as the benchmark. The problems above encourage the researcher to perform further study on the influence of arms muscle, pull length and archery technique upon archery achievement of the FITA recurve round.

\section{Theoretical Description}

\subsection{Archery Sport Achievement of the FITA Recurve Round}

The term of achievement, according to Act Number $3 / 2005 / \mathrm{SKN}$, is the result of maximum effort that is achieved by an athlete or team in a sport activity. On the other hand, Seidel (1975) relates achievement to skill of movement experienced in a change of time, place position as the result of strength development of a person's energy released during interaction with environment.

The achievement of an archer is being able to collect the highest possible point in $90 \mathrm{~m}, 70 \mathrm{~m}, 50 \mathrm{~m}$ and $30 \mathrm{~m}$ 
distance, by firing 144 arrows that are divided into these 4 varied distances. In each of the distances, it shall fire 36 arrows.

According to the description above, what is meant with archery sport achievement of the FITA recurve round is the maximum capability of an archer to get the highest possible total score, by firing 144 arrows in $90 \mathrm{~m}, 70 \mathrm{~m}$, $50 \mathrm{~m}$ and $30 \mathrm{~m}$ distances precisely onto the target with $122 \mathrm{~cm}$ diameter of target face for $90 \mathrm{~m}$ and 70 distances; and $80 \mathrm{~cm}$ diameter of target face for $50 \mathrm{~m}$ and $30 \mathrm{~m}$ distances.

\subsection{Archery Technique}

Archery technique in general, according to Kisik Lee and de Bondt (2005), consists of 9 stages: (1) stance (position/ standing posture), (2) nocking (putting arrow onto string), (3) hooking and gripping (preparing drawing fingers and gripping position), (3) pre draw, (5) drawing (full draw), (7) aiming and expansion (aiming onto target), (8) release (releasing string and arrow), (9) follow through (further movement).

\subsection{Draw Length}

Pull length, according to Haywood and Lewis (1989) is the extension of drawn bow, until the string reaches the nose, lips, and chin and is measured from the notch on nock to arrow rest. The matters that influence the pull length is anthropometric factors, in this case extension of arms. Given any movement in archery is performed with body sideway, and then the width of both of shoulders shall influence the pull length.

According to the description above, we may draw a conclusion that pull length is the extension of drawn bow until the string reaches nose, lips and chin when it uses correct archery technique.

\subsection{Arms Muscle Strength}

Strength, according to Dangsina Moeloek (1984), is defined as maximum force or torque (rotational force) that is resulted by muscle or a group of muscles. In addition, according to Bompa (1993), strength is defined as the power of neuromuscular system that results in force that resists any external resistance.

Muscle strength is the power of muscle or a group of muscles to make a maximum contraction. On the other hand, according to Bompa, the simple definition of strength is a capability to deliver energy. This is supported by Mochamad Soebroto (1977-1978), that muscle power is a quality that enables a development of muscle tension in a maximum contraction. According to the description above, we may draw a conclusion that strength is the power or quality of muscle or a group of muscles that contracts to overcome any load; either own body load or other than body load.

Pate (1993) defines arms muscle as muscles attached along arms bone, namely: (1) pectoralis major, (2) deltoids, (3) triceps brachii, (4) biceps brachii, (5) koraco brachialis, (6) brachialis, (7) brachioradialis, and (8) extensor carpiradialis longus.

The factors that influence arms muscle, according to Bompa (1994), are: (1) number of muscle fibers, (2) number of movement units that support most in performance, (3) power of muscle nerve in responding nerve impulses, (4) capillary density in muscle fibers, (5) source of energy at the time of contraction and (6) number of components composing available muscle fibers. According to the descriptions above, we may draw a conclusion that arms muscle strength is the power of muscle or a group of arms muscles to make a contraction or delivery of energy.

\section{Background of Study}

\subsection{Direct Influence of Muscle Strength to Archery Technique}

Arms muscle strength is the capital to perform an archery technique. Anyone may perform a correct archery technique when he/she has sufficient arms muscle strength to draw and hold the bow. In order to perform a correct archery technique, an athlete must be able to feel and control his/her technique well. A control upon technique is possible when the athlete is in a comfort zone, that he/she must be in relaxed condition (not experiencing excessive muscle tension) thus the point of concentration shall focus more to the archery technique.

Great strength of arms muscles may take an athlete into comfort zone, because at the time of drawing the bow, arms muscles in contraction do not experience excessive tension because high load of bow being drawn is far lower than maximum threshold of muscles strength. According to the description above, it is assumed that there is direct influence of muscle strength with archery technique.

\subsection{Direct Influence of Draw Length to Archery Technique}

Arrow's speed is one of the factors that determine the level of precision of an arrow in aiming its target. The higher the speed of the arrow will results in smaller angle of the trajectory of the parabola of the arrow. This will 
minimize any barrier from the influence of wind which can deflect the direction of the arrow. Technically, the influence is that, when drawing and holding the bow, the athlete does not require a great force, thus the control over the technique and target shall be more focused. In a long term, it may lead to consistency of technique. According to the description above, it is assumed that there is direct influence of draw length to archery technique.

\subsection{Direct Influence of Muscle Strength to Archery Achievement of the FITA Recurve Round}

In mechanical perspective, the accuracy in archery after the arrow is released from the bow is much influenced by weather factor, in this case wind blow. The higher wind blow, the higher deviation of arrow direction is. In order to make a pull using weight bow, there is a need of great strength of arms muscle to draw the bow. According to the description above, it is assumed that there is direct influence of arms muscle strength to archery achievement of the FITA recurve round.

\subsection{Direct Influence of Draw Length to Archery Achievement of the FITA Recurve Round}

After an arrow is released from the bow, the accuracy of the arrow is determined by its speed. The higher speed of the arrow results in smaller angle of the trajectory of the parabola of the arrow. Another factor that influences the arrow's speed is the extension of draw length. Longer/bigger extension results in the higher speed of the arrow being released. According to the description above, it is assumed that there is direct influence of extension of pull length to archery achievement of the FITA recurve round.

\subsection{Direct Influence of Archery Technique to Archery Achievement of the FITA Recurve Round}

The ability to apply archery technique plays a quite critical role in supporting the archery achievement. An archery technique is composed and created in consideration of biomechanic and anatomic aspects. In principle, the biomechanic aspect of a correct archery technique is how to release an arrow onto its target by minimizing any friction, draw, pounding and vibration on the bow that will result in change of arrow's direction. Anatomic aspect refers to how the body parts move from a locomotor system onto the system of other parts in consideration of physical fact, in this case body form. Based on the description above, it is assumed that there is direct influence of archery technique to archery achievement of the FITA recurve round.

\section{Hypotheses}

The hypotheses of this study are formulated as follows:

1) Arms muscle strength has direct influence to archery technique.

2) Draw length has direct influence to archery technique.

3) Arms muscle strength has directly positive influence on archery achievement of the FITA recurve round.

4) Draw length has directly positive influence to archery achievement of the round FITA recurve.

5) Archery technique has directly positive influence to archery achievement of the FITA recurve round.

\section{Methodology}

This study is intended to observe whether or not there is influence and how much is the influence of:

1) Direct influence of arms muscle on archery technique.

2) Direct influence of pull length on archery technique.

3) Direct influence of arms muscle on archery achievement of the FITA recurve round.

4) Direct influence of pull length to archery achievement of the FITA recurve round.

5) Direct influence of archery technique on archery achievement of the FITA recurve round.

The data of study is obtained from the Gelora Bung Karno archery ground Senayan Jakarta, the place where national archery championship took place

This study examines four variables, consisting of three exogenous variables and one endogenous variable. The exogenous variables consist of arms muscle strength $\left(\mathrm{X}_{1}\right)$, pull length $\left(\mathrm{X}_{2}\right)$ and archery technique $\left(\mathrm{X}_{3}\right)$ and the endogenous variable consists of archery achievement of the FITA recurve round $\left(\mathrm{X}_{4}\right)$.

In this study, the target population in use is the whole male athletes who took part in national archery championship in 2010, consisting of 200 athletes from 15 provincial managements.

The sample of this study is 62 male archery athletes of the FITA recurve round. It uses purposive sampling in this study. 
In this study, it uses an instrument of study to collect data. The instrument of study is made through several methods, such as (1) composing variable indicators of study, (2) composing instrument lattice, (3) performing instrument test, (4) performing test on the validity and reliability of instrument.

\section{Data Analysis}

Path analysis was used to examine the hypothesis of the study. Prior to hypothesis test, it first takes a test on the conditions that is a test to the normality of error estimate data using Liliefors test and signification of regressive coefficient and regressive linearity test.

\section{Results of Study and Discussion}

The data obtained in the field is further processed statistically through SPSS version 17.0. This stage results in the data of average score, standard deviation, and maximum and minimum score of each variable. The calculation results in average score for arms muscle strength $\left(\mathrm{X}_{1}\right)$, pull length $\left(\mathrm{X}_{2}\right)$ and archery technique $\left(\mathrm{X}_{3}\right)$, while endogenous variable consisting of archery achievements of the FITA recurve round $\left(\mathrm{X}_{4}\right)$ is respectively: 50.0645, 50.0323, 49.9516 and 49.9839. The standard deviation is respectively: 51; $48 ; 44$ and 43. In addition, the maximum scores are respectively: $80 ; 72 ; 70$ and 76 . Whereas the minimum scores are respectively: 29; 28 ; 26 and 33 .

The summary of the hypothetical test results through line coefficient calculation and test that explains the influence of arms muscle strength, pull length and archery technique to archery achievement can be observed in the following table:

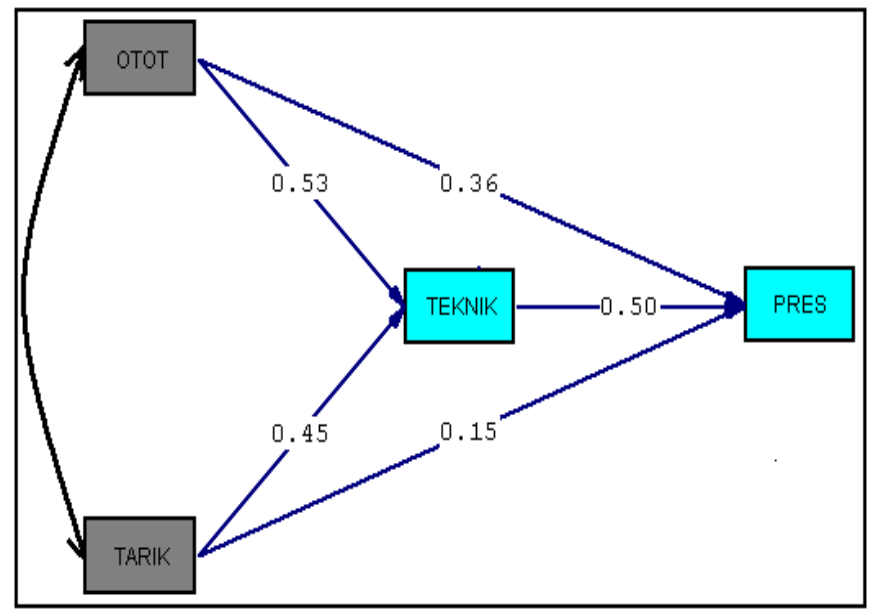

Figure 1. Standardized loading factor Hasil path analysis

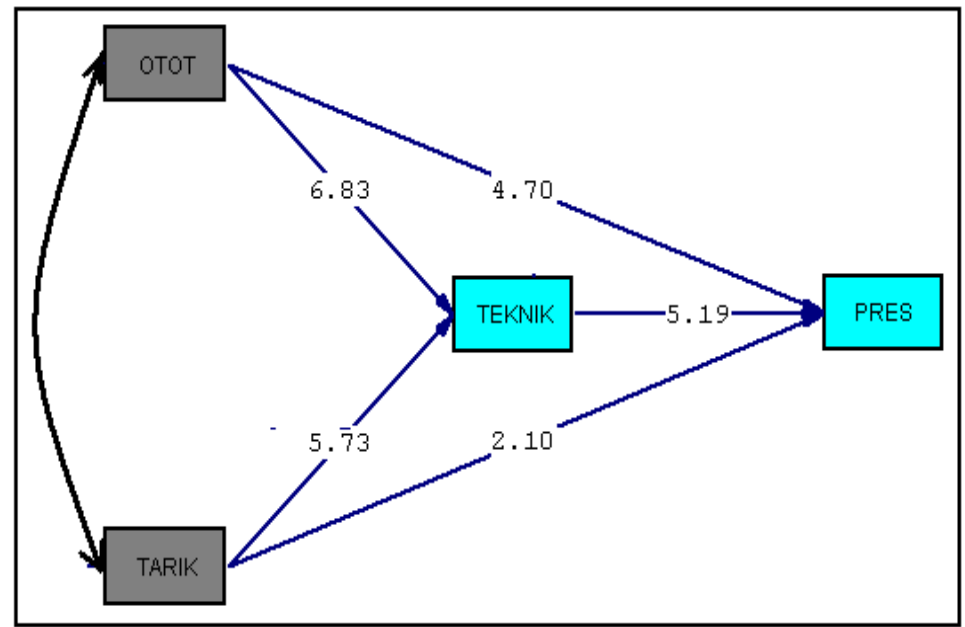

Figure 2. T-value results of path analysis 
According to the whole results of calculation above, it is clear that all of line coefficient (p) has positive loading

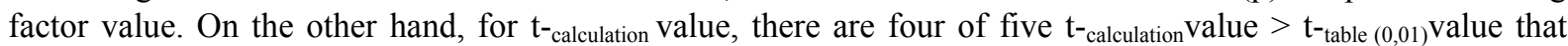
means that exogenous influence to endogenous factor is quite significant and there is one $t$-calculationvalue $>t-$ table $(0,05)$ value that means that the exogenous influence to endogenous factor is significant.

The calculation results in structural equation for archery technique, as follows:

$$
X_{3}=0,53 X_{1}+0,45 X_{2}
$$

\subsection{Substructural Equation-1}

Based on the substructural equation-1 above, it is objectively described as follows:

1) The directly positive influence of arms muscle strength $\left(X_{1}\right)$ to archery technique $\left(X_{3}\right)$ is $(0.53)^{2}=0.2809$ or $28.09 \%$ and based on $\mathrm{t}$-test, the influence is quite significant.

2) The directly positive influence of pull length $\left(X_{2}\right)$ to archery technique $\left(X_{3}\right)$ is $(0.45)^{2}=0.2025$ or $20.25 \%$ and based on t-test, the influence is quite significant.

3) The contribution of arms muscle strength $\left(X_{1}\right)$ and pull length $\left(X_{2}\right)$ simultaneously or jointly and directly influences archery technique $\left(\mathrm{X}_{3}\right)$ for 0,84 or $84,00 \%$. The remaining $16.00 \%$ is influenced by other factor that is beyond the description of substructural equation-1.

Furthermore, for archery achievement variable $\left(\mathrm{X}_{4}\right)$, it results in substructural equation-2 as follows:

$$
\mathrm{X}_{4}=0,36 \mathrm{X}_{1}+0,15 \mathrm{X}_{2}+0,50 \mathrm{X}_{3}
$$

\subsection{Substructural Equation-2}

According to the substructural equation-2 above, it is objectively described as follows:

1) The directly positive influence of arms muscle strength $\left(X_{1}\right)$ to archery achievement of the FITA recurve round $\left(\mathrm{X}_{4}\right)$ is $(0.36)^{2}=0.1296$ or $12.96 \%$, and based on t-test, the influence is quite significant.

2) The directly positive influence of pull length $\left(\mathrm{X}_{2}\right)$ to archery achievement of the FITA recurve round $\left(\mathrm{X}_{4}\right)$ is $(0.15)^{2}=0,0225$ or $2.25 \%$ and based on t-test, the influence is quite significant.

3) The directly positive influence of archery technique $\left(\mathrm{X}_{3}\right)$ to archery achievement of the FITA recurve round $\left(\mathrm{X}_{4}\right)$ is $(0.50)^{2}=0.2500$ or $25.00 \%$ and based on t-test, the influence is quite significant.

4) The contribution of arms muscle strength $\left(X_{1}\right)$, pull length $\left(X_{2}\right)$ and archery technique $\left(X_{3}\right)$ simultaneously or jointly and directly influence archery achievement of the FITA recurve round $\left(\mathrm{X}_{4}\right)$ for 0.9100 or $91,00 \%$. The remaining $9.00 \%$ is influenced by other factor that is beyond the description of substructural equation- 2 .

\section{Conclusion, Implication and Suggestion}

\subsection{Conclusion}

Based on the data analysis and statistical calculation in the previous chapters, we can draw a conclusion that:

1) Arms muscle strength has direct influence to archery technique.

2) Pull length has direct influence to archery technique.

3) Arms muscle strength has direct influence to archery achievement of the FITA recurve round.

4) Pull length has direct influence to archery achievement of the FITA recurve.

5) Archery technique has direct influence to archery achievement of the round FITA recurve round

\subsection{Suggestion}

According to the conclusion of result of study and implication as outlined above, the following suggestion is proposed:

1) For coach, it is supposed to improve archery achievement with regard to body anthropometry and development of physical components, primarily arms muscle strength, pull length and archery technique.

2) For PP. PERPANI, in selecting potential athletes, it shall primarily consider body anthropometry and development of physical components, primarily arms muscle strength, pull length and archery technique.

3) For athletes, they should take serious exercise, referring to the planned program.

4) For sports academician, further research should be conducted by involving other variables of biomotoric aspec, anthropometric aspec, mental aspect and tool aspect that may influence archery achievement. 
5) This study is made on male athletes without involving female athletes. Consequently, any other similar study may be performed by using female archers as sample.

\section{References}

Baechie, T. R., \& Barney, R. G. (2000). Strength and Conditioning Specialist. terjemahan R. Siregar. Jakarta: Rajagrafindo.

Baumgarner, T. A. (1982). Measurement for Evaluation in Physical Education and Exercise Science. Dubugue Iowa: Brown Cammunications Inc.

Beverly et al. (1975). Sport Skills. Iowa: WM. C. Brown Company Publishers.

Bompa, T. O. (1993). Periodization of Strength: The New Wave in Strength Training. Toronto, Ont. M6A-3C8 Canada: Veritas Publishing Inc.

Bompa, T. O., \& Haff, G. G. (2009). Periodization: Theory and Methodology of Training. Iowa: Human Kinetics.

Bouchard, D. (1975). Problem of Sport Medicine, Sport, Training and Coaching Education. Boston: Sport Olympic Solidarity, IOC.

Bowers, R. W., \& Fox, E. L. (1988). Sports Physiology. Dubuque, IA 52001: Wm. C. Brown Publishers.

Chu, D. A. (1992). Jumping into Plyometric. Champaign, Illinois: Human Kinetics Pub.

Coker, C. A. (2004). Motor Learning and Control Practitioners. New Mexico: McGraw Hill.

Dal Monte, A. (1978). Klasifikasi Kegiatan Olahraga dalam Masalah-Masalah Kedokteran Olahraga, Latihan Olahraga dan Coaching. terjemaahan Moh. Soebroto. Jakarta: Ditjen Diklusepora. Depdikbud.

Damiri, A. (1990). Panahan. Bandung: FPOK-IKIP Bandung.

Diana. (2000). Special Trainning Techniques and Training Aids Part II Reference Manual. Illions: Human Kinetics Books.

FITA. (2010). Constitutional and Rules. International Archery Federation.

Fox, E. L., \& Mathew, D. K. (1981). The Physiological Basis of Physical Education and Athletics. Philadelpia: Saunders College Pub.

Fox., \& Mathews. (1986). The Physicological Bases of Physical Education and Athletics. New York: Holt Wb Saunders Co.

Furqon, M. H., \& Doewes, M. (2000). Analisis Kebutuhan Fisik dan Implikasi dalam Olahraga Panahan. Jakarta: Litbang KONI Pusat dan Puslitbang-OR UNS,.

Godfrey, R. (2006). Detraining - Why a change really is better than a rest. Retrieved November 20, 2010, from http://www.pponline.co.uk/encyc/detraining.htm

Guyton, C. A., \& Hall, J. E. (1977). Buku Ajar Fisiologi Kedokteran (9th ed.). Jakarta: EGC.

Harre, D. (1982). Principles of Sport Training. Berlin: Sportverlag.

Harsono. (1988). Coaching dan Aspek-Aspek Psikologis dalam Coaching. Jakarta: P2LPTK, Departemen Pendidikan Nasional.

Harsuki. (2003). Perkembangan Olahraga Terkini Kajian Para Pakar. Jakarta: Raja Grafindo Persada.

Haywood, C. M., \& Lewis, C. F. (1989). Archery Step to Success. Champaign, Illinois: Leisure Press.

Humaid, H. (2003). Hubungan Kekuatan Ekstremitas Superior dan Panjang Tarikan dengan Prestasi Panahan Ronde Nasional. Tesis. PPS. UNJ. Retrieved Nopember 22, 2009, from http://www.archery-tips.com/archerytips/archery-tips-for-beginners

Jeffrey, G. (2006). The 10 Step. Centenary Archers Club.

Joseph, N. (1982). General Theory of Training. Lagos: Pan African Press.

Kim, H. T. (2007). Archery. Seoul: Kim, Hyung Tak, Archery Trainning Center.

Kiram, Y. (1992). Belajar Motorik. Jakarta: Depdikbud Ditjen Dikti.

Komi, P. V. (1992). Strength and Power in Sport. Oxford: Blackwell Scientific Publication.

Lee, K., \& Bondt, R. (2005). Total Archery. Seoul: Samick Sports Co. Ltd. 
McKinney, R., \& Yoshi, K. (1977). The Confident Shoot. Tokyo: Sakamoto-Kikakishitsu Co. Ltd.

Moeloek, D. (1984). Kesehatan dan Olahraga. Jakarta: Fakultas Kedokteran Universitas Indonesia.

Nurhasan. (2001). Tes dan Pengukuran dalam Pendidikan Jasmani: Prinsip dan Penerapannya. Jakarta: Depdiknas.

Pate, R. R., Clenaghan, B. M., \& Rotela, R. (1993). Dasar-Dasar Ilmiah Kepelatihan, terjemahan Kasiyo Dwijowinoto. Semarang: IKIP Semarang Press.

PERPANI. (1988). Pendataan Induk Organisasi Olahraga. Jakarta: PERPANI.

Putrawan, I. M. (1990). Pengujian Hipotesis dalam Penelitian-Penelitian Sosial. Jakarta: Rineka Cipta.

Rahamntoknam, B. E. (1988). Belajar Motorik Teori dan Aplikasinya dalam Pendidikan Jasmani dan Olahraga. Jakarta: P2LPTK Dirjen Dikti Depdikbud.

Riduwan, E. A. K. (2008). Cara Menggunakan dan Memaknai Analisis JalurPath Analysis. Bandung: Alfabeta.

Santoso, S. (2005). Statistik Parametrik. Jakarta: PT. Elex Media Komputindo.

Sharkeys, B. J. (1986). Coaches Guide for Sport. Champaign, Illionis: Human Public Kinetics.

Shumway, \& Woollacott. (2001). Motor Control: Theory and Practical Applications. Philadelphia: Lippincott Williams \& Wilkins.

Soebroto, M. (1977-1978). Masalah-masalah dalam Kedokteran Olahraga Latihan Olahraga dan Coaching. Jakarta: Direktorat Jendral Pendidikan Luar Sekolah dan Olahraga, Departemen Pendidikan dan Kebudayaan RI, DIP Tahun.

Sudarno. (1992). Pendidikan Kesegaran Jasmani. Jakarta: Departemen P dan K.

Sudjana. (1996). Metode Statistika. Bandung: Transito.

Undang-Undang Nomor 3 tahun 2005 tentang Sistem Keolahragaan Nasional.

\section{Copyrights}

Copyright for this article is retained by the author(s), with first publication rights granted to the journal.

This is an open-access article distributed under the terms and conditions of the Creative Commons Attribution license (http://creativecommons.org/licenses/by/3.0/). 